\title{
Digested wheat gluten inhibits binding between leptin and its receptor
}

Tommy Jönsson ${ }^{1 *}$, Ashfaque A Memon ${ }^{1}$, Kristina Sundquist ${ }^{1}$, Jan Sundquist ${ }^{1}$, Stefan Olsson ${ }^{2}$, Amarnadh Nalla ${ }^{3,4}$, Mikael Bauer ${ }^{5}$ and Sara Linse ${ }^{5}$

\begin{abstract}
Background: Leptin resistance is considered a primary risk factor for obesity. It has been hypothesized that dietary cereal grain protein could cause leptin resistance by preventing leptin from binding to its receptor. Non-degraded dietary wheat protein has been found in human serum at a mean level of $41 \mathrm{ng} / \mathrm{mL}$. Here, we report our findings from testing whether enzymatically digested gluten from wheat prevents leptin from binding to the leptin receptor in vitro.

Gluten from wheat was digested with pepsin and trypsin under physiological conditions. Pepsin and trypsin activity was removed from the gluten digest with a $10 \mathrm{kDa}$ spin-filter or by heat treatment at $100^{\circ} \mathrm{C}$ for $30 \mathrm{~min}$. Binding to the leptin receptor of leptin mixed with gluten digest at a series of concentrations was measured using surface plasmon resonance technology.

Results: Binding of the gluten digest to the leptin receptor was not detected. Spin-filtered gluten digest inhibited binding of leptin to the leptin receptor, with $50 \%$ inhibition at a gluten digest concentration of $\sim 10 \mathrm{ng} / \mathrm{mL}$.

Heat-treated gluten digest did not inhibit leptin binding.

Conclusions: Digested wheat gluten inhibits binding of leptin to the leptin receptor, with half-maximal inhibition at $10 \mathrm{ng} / \mathrm{mL}$. The inhibition is significant at clinically relevant concentrations and could therefore serve as a novel pathway to investigate to understand the molecular basis of leptin resistance, obesity and associated disorders.
\end{abstract}

Keywords: Gluten, Leptin, Leptin resistance, Obesity

\section{Background}

Leptin is a $16-\mathrm{kDa}$ polypeptide secreted by white adipose tissue into the circulation, as recently reviewed by Zhou et al. [1]. Circulating leptin levels are proportional to body fat mass and fluctuate in accordance with changes in nutritional states. The leptin concentration serves as a key adiposity signal for the brain, where leptin binds to and activates the leptin receptor. Leptin is important in regulating satiety, weight and energy homeostasis. Most obese patients have high levels of circulating leptin, indicating an acquired state of leptin resistance, defined by the reduced ability of leptin to suppress appetite and weight gain [2]. Leptin resistance is considered a primary risk factor for the pathogenesis of overweight and obesity [2], which in turn is closely associated with various

\footnotetext{
* Correspondence: Tommy.Jonsson@med.lu.se

${ }^{1}$ Center for Primary Health Care Research, Lund University/Region Skåne,

Skåne University Hospital, Malmö, Sweden

Full list of author information is available at the end of the article
}

metabolic disorders including dyslipidemia, cardiovascular disease, stroke, insulin resistance and type 2 diabetes. Several mechanisms have been proposed to explain leptin resistance, including impaired leptin transport, leptin signaling and leptin-targeted neural circuits [2].

It has been hypothesized that dietary cereal grain protein could cause leptin resistance by preventing leptin from binding to the leptin receptor [3]. Briefly, the hypothesis rests on the following propositions: (I) The global pattern of varying prevalence of diseases of affluence, such as obesity, cardiovascular disease and diabetes, suggests that some environmental factor specific to agrarian societies could initiate these diseases; (II) A diet based on cereal grain could be such an environmental factor; (III) Leptin resistance is also associated with diseases of affluence and could be a sign of insufficient adaptation to a diet based on cereal grain; (IV) Cereal grain proteins have sufficient properties (i.e. they are unique, are present in human food, are heat-stable, are resistant to 
gastro-intestinal breakdown, enter the human circulation, and bind to cell surfaces and receptors) to cause leptin resistance by inhibiting binding of leptin to the leptin receptor. The hypothesis is supported by a recent study on human genetic adaptation by Segurel et al., which showed positive selection of protective variants of the leptin receptor with regard to type 2 diabetes from the Neolithic period onward [4]. This indicates the onset of evolutionary pressure on the leptin receptor when significant amounts of cereal grain were adopted as food. Support also comes from animal studies, which show that dietary components can induce leptin resistance in rats in relatively short periods of time at normal body weight and leptin levels [5]. Dall et al. demonstrated that cereal grain protein in the form of digested wheat gliadin caused a $20 \%$ increase in weight gain when injected into non-obese diabetic (NOD) mice in a prediabetic state [6], possibly indicating the induction of leptin resistance. Dall et al. also demonstrated that digested wheat gliadin caused a dose-dependent increase in insulin secretion when incubated with rat insulinoma cells and rat islets, which was possibly caused by inhibition of current through ATP-sensitive $\mathrm{K}+\left(\mathrm{K}_{\mathrm{ATP}}\right)$ channels [6]. These findings could be indirect evidence that digested wheat gliadin actually inhibits leptin binding, since leptin was previously reported to cause the opposite effect in insulinoma cells [7]. Further support comes from human clinical studies, in which El-Shebini et al. found that indices of leptin resistance are improved by replacing bread with vegetables in otherwise similar hypocaloric diets and with similar weight loss [8]. Another study by Ryberg et al. on the effects of a diet without cereal grains also showed significant effects on leptin [9]. Our previous dietary intervention study comparing effects of diets with and without cereal grains showed a strong correlation between relative change in leptin and cereal grain intake [10].

In this study, we tested the last proposition of the above hypothesis, which is that cereal grain proteins inhibit leptin binding. Cereal grain proteins have already been reported to bind to a receptor by Lammers et al., who found that cereal grain peptides derived from enzymatic digestion of wheat gliadin with the gut enzymes pepsin and trypsin under physiological conditions bind to the chemokine receptor CXCR3 expressed in mouse and human intestinal epithelia and laminae propriae, leading to zonulin release and increased intestinal permeability [11]. Kamikubo et al. reported that wheat germ agglutinin binds to the leptin receptor in vitro and inhibits binding of leptin to the leptin receptor [12]. Wheat germ agglutinin is found in common wheat flour but not in human blood [13]. We chose to examine cereal grain protein from wheat, which is the main source of vegetable protein in human food. The main protein component of wheat is gluten, which is the cohesive and elastic mass that remains after starch has been removed from cereal grain flour by rinsing with water. More specifically, wheat gluten is a composite of several kinds of proteins, such as gliadins (molecular weight $\sim 30 \mathrm{kDa}$ ) and glutenins (molecular weight $\sim 30$ $90 \mathrm{kDa}$ ). Gluten intake has increased greatly over the last hundred years and has accelerated during the last few decades $[14,15]$. This increase is largely due to breeding of gluten-rich cereal grain varieties and most recently by the use of extra gluten in baking and food processing to make dough easier to work and bread fluffier [15]. Soares et al. found that a gluten-free diet reduces leptin, adiposity, inflammation and insulin resistance in mice despite a similar energy intake [16]. Chirdo et al. reported the presence of non-degraded wheat gliadin in human serum (at a mean level of $41 \mathrm{ng} / \mathrm{mL}$ ) [17], as previously also reported for other dietary proteins by Husby et al. [18,19].

Here, we used surface plasmon resonance (SPR) technology to monitor the interaction between leptin and the leptin receptor and its inhibition by enzymatically digested gluten from wheat.

\section{Methods \\ Digestion of gluten}

To mimic physiological conditions in the human intestine, gluten from wheat was digested according to the protocol of De Ritis et al. [20] with slight modifications. $100 \mathrm{~g}$ of gluten from wheat (Sigma-Aldrich: G5004) was digested in $1 \mathrm{~L}$ of $0.2 \mathrm{~N} \mathrm{HCl}(\mathrm{pH} 1.8)$ containing $2 \mathrm{~g}$ of pepsin (Sigma-Aldrich: P6887) at $37^{\circ} \mathrm{C}$ for 2 hours. The $\mathrm{pH}$ was checked periodically and adjusted to 1.8 with $\mathrm{HC} 1$ or $\mathrm{NaOH}$ as necessary. The $\mathrm{pH}$ was then adjusted to 8.0 with $2 \mathrm{~N} \mathrm{NaOH}$. The pepsin-digested gluten was further digested by addition of $2 \mathrm{~g}$ of trypsin (Sigma-Aldrich: T4799). The resulting pepsin- and trypsin-digested gluten was vigorously stirred at $37^{\circ} \mathrm{C}$ for $4 \mathrm{~h}$. The $\mathrm{pH}$ was checked periodically and adjusted to $\mathrm{pH} 8.0$ with $\mathrm{HC} 1$ or $\mathrm{NaOH}$ as necessary.

\section{Pepsin and trypsin removal}

Pepsin (molecular weight $\sim 40 \mathrm{kDa}$ ) and trypsin (molecular weight $\sim 25 \mathrm{kDa}$ ) were removed from the gluten digest by either spin-filtering through a $10 \mathrm{kDa}$ filter or heat-treatment at $100^{\circ} \mathrm{C}$ for $30 \mathrm{~min}$ followed by centrifugation at $13000 \mathrm{~g}$ for $10 \mathrm{~min}$. The gluten digest concentration after filtering or centrifugation was determined from the absorbance at $280 \mathrm{~nm}$, assuming an absorbance of 1 at $1 \mathrm{mg} / \mathrm{mL}$. To check whether any pepsin or trypsin activity remained, $1.8 \mu \mathrm{g} / \mathrm{mL}$ leptin (recombinant human leptin, $R \& D$ Systems) was incubated in gluten digest (spin-filtered only or spin-filtered and heat-treated) for $1 \mathrm{~h}$ or $24 \mathrm{~h}$ at $37^{\circ} \mathrm{C}$. The samples were resolved by SDS PAGE 
(Invitrogen) and were blotted using the Blot $^{\oplus}$ Gel Transfer Stacks, PVDF, mini kit (Invitrogen) according to the manufacturer's instructions. After washing, the blots were incubated with anti-leptin HRP-conjugated antibody (HyTest Ltd, cat. \# 2LE1C) at $4^{\circ} \mathrm{C}$ overnight. The antibody was used at a 1:1000 dilution relative to the stock concentration in the product (HyTest Ltd, cat. \# 2LE1C). Immunoreactive bands were detected using ECL reagents (GE Healthcare Life Sciences).

\section{SPR studies}

All SPR experiments were performed using the Biacore 3000 system (Biacore AB, Uppsala, Sweden) and Sensor Chips coated with carboxylated dextran (CM5, GE Healthcare). The flow rate was $10 \mu \mathrm{L} / \mathrm{min}$ throughout immobilization and all experiments. Immobilization of human leptin receptor/Fc chimera (R\&D Systems 389LR) was performed using amine coupling with HBS-EP running buffer (10 mM HEPES, 3.4 mM EDTA, $150 \mathrm{mM} \mathrm{NaCl}, 0.005 \%$ Tween 20, pH 7.4). The Sensor Chip surface was activated by injecting a solution of $0.05 \mathrm{M}$ NHS and $0.2 \mathrm{M}$ EDC in water (mixed just prior to injection) for $7 \mathrm{~min}$, followed by a short buffer rinse. Coupling was achieved by injecting $100 \mu \mathrm{l}$ of human leptin receptor/Fc chimera in $10 \mathrm{mM}$ sodium acetate buffer ( $\mathrm{pH}$ 5.0) into three flow cells at concentrations of 1,3 and $10 \mu \mathrm{g} / \mathrm{mL}$. One channel received no receptor to serve as a blank control. All four flow cells were blocked by injection of $70 \mu \mathrm{l}$ of $1 \mathrm{M}$ ethanolamine ( $\mathrm{pH} 8.5$ ), followed by buffer flow for at least 2 h. Association of human leptin (R\&D Systems: 398-LP) was monitored by injection of $30 \mathrm{nM}$ leptin for $10 \mathrm{~min}$, and its dissociation was monitored by buffer flow for up to $15 \mathrm{~h}$. The instrument reports the amount bound per surface area in RU ( $\left.1 \mathrm{RU}=1 \mathrm{ng} / \mathrm{mm}^{2}\right)$, as derived from the angle of minimum total internal reflection of the incident light. The experiment was repeated three times for a series of $30 \mathrm{nM}$ leptin samples with increasing concentrations of gluten digest (heat-treated or spin-filtered) ranging from $0.9 \mathrm{ng} / \mathrm{mL}$ to $450 \mu \mathrm{g} / \mathrm{mL}$. In these experiments, the association of leptin was monitored for $10 \mathrm{~min}$ and dissociation for $5 \mathrm{~min}$. Dissociation was followed by regeneration by injection of $25 \mathrm{mM}$ glycine/ $\mathrm{HCl}(\mathrm{pH} 2.5)$ for $7 \mathrm{~min}$.

The dissociation phase data were fitted using a single exponential decay:

$$
\mathrm{I}=\mathrm{I}_{0} \cdot \mathrm{e}^{-\mathrm{koff} \cdot \mathrm{t}}+\mathrm{R}_{\infty}
$$

The value obtained for $\mathrm{k}^{\text {off }}$ was then used during fitting of the association phase data to obtain an estimate of $\mathrm{k}^{\mathrm{on}}$ with the following equation:

$$
\begin{aligned}
I= & R_{\max } \cdot c \cdot k^{o n} \cdot\left(1-e^{-(c \cdot k o n+k o f f) \cdot t}\right) /\left(c \cdot k^{o n}+k^{o f f}\right) \\
& +R_{\infty}
\end{aligned}
$$

The inhibition data were analyzed by finding the plateau value at the end of each injection of leptin alone or leptin plus gluten digest.

\section{Results}

Pepsin and trypsin removal

Western blotting showed remaining leptin bands for all gluten digests after both 1 and $24 \mathrm{~h}$. This shows that spin-filtering and heat treatment removed all protease activity in the gluten digest since leptin would otherwise have been degraded.

\section{SPR studies}

Attempts to monitor binding of gluten digest to the leptin receptor suffered from too low a signal-to-noise ratio and were therefore inconclusive. Instead, we studied binding to the leptin receptor of leptin alone and leptin mixed with gluten digest at a series of concentrations. Leptin alone was found to interact with the leptin receptor with high affinity $\left(\mathrm{k}^{\text {off }}=4.3 \cdot 10^{-4} \mathrm{~s}^{-1}, \mathrm{k}^{\text {on }}=6.410^{5} \mathrm{M}^{-1} \mathrm{~s}^{-1}, \mathrm{~K}_{\mathrm{D}}=0.6\right.$ $\mathrm{nM}$, Figure $1 \mathrm{~A}, \mathrm{~B})$, in line with earlier findings [21]. The heat-treated gluten digest did not inhibit binding of leptin to the leptin receptor. However, the spin-filtered gluten digest reduced binding of leptin to the leptin receptor in a concentration-dependent manner. Examples of SPR sensorgrams for a few concentrations of spin-filtered gluten digest are shown in Figure 1A, with the relative concentration of bound leptin at the plateau value shown for all concentrations in Figure 1C (see below). While experiments with non-purified proteolytic gluten digest would suffer from potential digestion of the receptor on the chip, we here evaluated two methods for protease inactivation/ removal. While heat treatment followed by centrifugation seems to remove all protease activity (leptin bound with an undiminished signal during repeated injections), it also removed all leptin-inhibiting activity from the gluten digest. The use of molecular weight filters was successful and seems to remove all protease activity while leaving leptininhibiting activity intact in the remaining filtrate. The final leptin binding plateau value obtained in the absence or presence of the filtrated gluten digest is plotted versus the logarithm of the gluten digest concentration (Figure 1C). The gluten digest was found to dose-dependently inhibit binding of leptin to the leptin receptor. A sigmoidal curve was obtained, with half-maximal inhibition of leptin binding at a gluten digest concentration of $\sim 10 \mathrm{ng} / \mathrm{mL}$. 

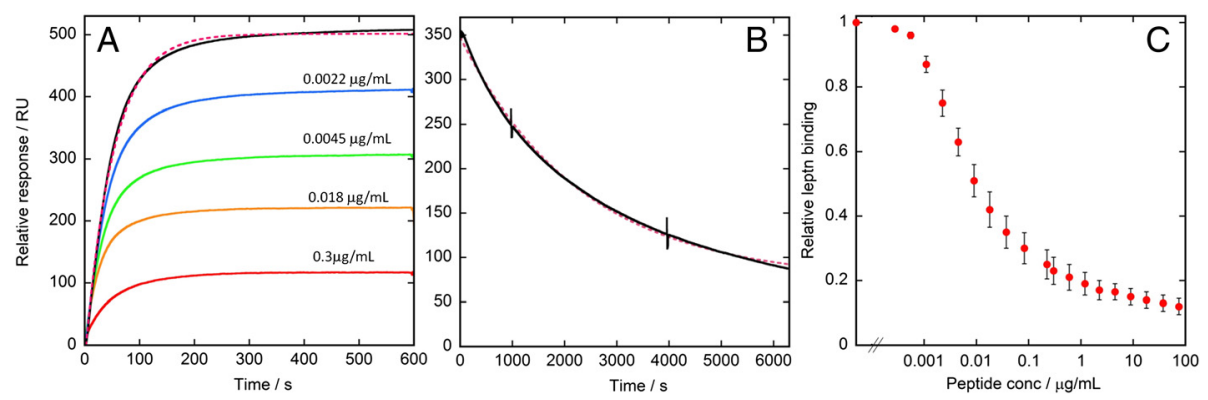

Figure 1 SPR analysis of binding of leptin to the leptin receptor and its inhibition by the gluten digest. A) Examples of sensorgrams recorded during the injection of $30 \mathrm{nM}$ leptin alone (black) or in the presence of 0.0022 (blue), 0.0045 (green), 0.018 (orange) or 0.3 (red) $\mu \mathrm{g} / \mathrm{mL}$ gluten digest over a Sensor Chip with immobilized leptin receptor-Fc chimera. The pink dashed line is a fit to the black line using equation 2 (see Methods). B) Example of a sensorgram recorded during buffer flow after complete injection of $30 \mathrm{nM}$ leptin (black). The pink dashed line is a fit to the data using equation 1 (see Methods). The two vertical lines occur during the extended time dissociation when the machine switches between its two pumps. C) Plot of relative intensity at the final leptin binding plateau during injection of $30 \mathrm{nM}$ leptin versus gluten digest concentration. The error bars represent the standard deviation of three measurements.

\section{Discussion}

\section{Key findings}

Digested wheat gluten inhibits binding of leptin to the leptin receptor.

\section{Possible mechanisms}

No binding of gluten digest to the leptin receptor was detected. This may indicate that digested gluten was too small to detect when bound to the leptin receptor or that digested gluten instead bound to leptin. Regardless, the gluten digest may inhibit leptin binding directly by obstructing the binding site on leptin or the leptin receptor, or indirectly by causing a conformational change in leptin or the leptin receptor that disturbs their ability to bind one another.

\section{Comparison with findings from other studies}

Lammers et al. showed that gluten digest caused concentration-dependent displacement of the CXCR3 receptor ligand, with 50\% ligand displacement with a gluten digest concentration of $1 \mathrm{mg} / \mathrm{mL}$ [11]. The much lower gluten digest concentration of $10 \mathrm{ng} / \mathrm{mL}$ needed in our study for half-maximal inhibition of leptin binding could be due to sensitivity differences in the studies' respective binding model. It could also be due to concentration and/or activity differences between the inhibiting substances in the respective gluten digests.

\section{Limitations of the present study}

This is an in vitro study and more research has to be performed to clarify the possible clinical relevance of our observations. Also, the study examined effects of wheat gluten, thus leaving other wheat proteins and all other cereal grain proteins for future studies. Furthermore, protease activity was removed from the gluten digest by spin-filtering through a $10 \mathrm{kDa}$ filter. This will have removed larger possibly active substances from the gluten digest. Such substances can be examined in future studies.

\section{Research and clinical implications}

The concentrations at which digested wheat gluten inhibited leptin in our study are in the same range as the concentrations previously reported for gliadin and other dietary proteins in human serum [17-19], thus making cereal grain proteins clinically relevant as a possible cause of leptin resistance and obesity. Our findings warrant further research, not only on the effects of proteins from wheat and other cereal grains on leptin signalling, but also on the effects of other dietary proteins on other receptors, structures and functions in the body.

To assess the clinical implications of the study results, we should consider previous findings on the relationship between serum leptin and body fat mass in humans, which was found to be a strong linear or quadratic correlation $(\mathrm{R}=0.86, \mathrm{P}<0.0001$ for the linear correlation and $\mathrm{R}=$ $0.85, \mathrm{P}<0.001$ for the quadratic correlation), as measured by underwater weighing or bioelectric impedance analysis $[22,23]$. Also, another study showed that there was a linear relationship between serum leptin and cerebrospinal fluid leptin in lean individuals $(\mathrm{R}=0.41, \mathrm{P}<0.05)$ [24]. Such correlations are of course not certain indications of a causal connection and most certainly oversimplify the mechanisms causing obesity. However, if there were a causal linear relationship between leptin level and body fat mass, a tentative $50 \%$ reduction in binding of leptin to the leptin receptor due to continual intake of cereal grain proteins would lead to a doubling of body fat mass. Furthermore, for an adult with $20 \%$ body fat mass, a doubling of body fat mass would increase body mass index (BMI) by 20\%. This is the difference between current mean BMI among Swedish adults of $\sim 25 \mathrm{~kg} / \mathrm{m}^{2}$ 
and a healthier $\sim 21 \mathrm{~kg} / \mathrm{m}^{2}$. A corresponding BMI improvement would probably also reduce obesity-associated metabolic disorders such as dyslipidemia, cardiovascular disease, stroke, insulin resistance and type 2 diabetes in the population.

\section{Conclusions}

Digested wheat gluten inhibits binding of leptin to the leptin receptor, with half-maximal inhibition at $10 \mathrm{ng} / \mathrm{mL}$. The inhibition is significant at clinically relevant concentrations and could therefore serve as a new pathway to investigate to understand the molecular basis of leptin resistance, obesity and associated disorders.

\section{Competing interests}

The authors declare that they have no competing interests.

\section{Authors' contributions}

TJ conceived the study, participated in the design of the study and wrote the article. AM, KS, JS, SO, AN, MB and SL participated in the design and execution of the study and the drafting of the article, as well as revising it for important intellectual content. All authors read and approved the final manuscript.

\section{Acknowledgements}

The authors are grateful to Anna Hedelius for technical assistance and to Dr De Vincenzi and Dr Silano at Istituto Superiore di Sanità in Rome, Italy, for kindly sending us their wheat digest for initial experiments. The study was funded by Skåne University Hospital Foundations and Endowments (SUS stiftelser och donationer) and Dr P Håkanssons stiftelse.

\section{Author details}

'Center for Primary Health Care Research, Lund University/Region Skåne, Skåne University Hospital, Malmö, Sweden. ${ }^{2}$ Department of Plant and Environmental Science, University of Copenhagen, DK-1871 Frederiksberg C, Denmark. ${ }^{3}$ Institute of Biomedical Sciences, Faculty of Health and Medical Sciences, University of Copenhagen, DK-2200 Copenhagen, Denmark. ${ }^{4}$ The Danish Diabetes Academy, Odense University Hospital, Odense, Denmark. ${ }^{5}$ Department of Biochemistry and Structural Biology, Lund University, Lund, Sweden.

Received: 18 August 2014 Accepted: 12 January 2015

Published online: 20 January 2015

\section{References}

1. Zhou Y, Rui L. Leptin signaling and leptin resistance. Front Med. 2013:7(2):207-22.

2. Pan H, Guo J, Su Z. Advances in understanding the interrelations between leptin resistance and obesity. Physiol Behav. 2014;130:157-69.

3. Jonsson T, Olsson S, Ahren B, Bog-Hansen TC, Dole A, Lindeberg S. Agrarian diet and diseases of affluence - Do evolutionary novel dietary lectins cause leptin resistance? BMC Endocr Disord. 2005;5(1):10.

4. Segurel L, Austerlitz F, Toupance B, Gautier M, Kelley UL, Pasquet P, et al. Positive selection of protective variants for type 2 diabetes from the Neolithic onward: a case study in Central Asia. Eur J Hum Genet. 2013;21(10):1146-51.

5. Vasselli JR, Scarpace PJ, Harris RB, Banks WA. Dietary components in the development of leptin resistance. Adv Nutr. 2013:4(2):164-75.

6. Dall M, Calloe K, Haupt-Jorgensen M, Larsen J, Schmitt N, Josefsen K, et al. Gliadin fragments and a specific gliadin 33-mer peptide close KATP channels and induce insulin secretion in INS-1E cells and rat islets of Langerhans. PLoS One. 2013;8(6):e66474

7. Lam NT, Cheung AT, Riedel MJ, Light PE, Cheeseman Cl, Kieffer TJ. Leptin reduces glucose transport and cellular ATP levels in INS-1 beta-cells. J Mol Endocrinol. 2004;32(2):415-24.

8. El-Shebini SM, Ghattas LA, Mohamed HI, Moaty MI, Tapozada ST, Hanna LM. Circulating concentrations of leptin hormone, soluble leptin receptor and free leptin index in obese egyptian women before and after diet therapy. J Med Sci. 2009:9(5):219-26.

9. Ryberg M, Sandberg S, Mellberg C, Stegle O, Lindahl B, Larsson C, et al. A Palaeolithic-type diet causes strong tissue-specific effects on ectopic fat deposition in obese postmenopausal women. J Intern Med. 2013;274(1):67-76.

10. Jonsson T, Granfeldt Y, Erlanson-Albertsson C, Ahren B, Lindeberg S. A paleolithic diet is more satiating per calorie than a mediterranean-like diet in individuals with ischemic heart disease. Nutr Metab (Lond). 2010;7:85.

11. Lammers KM, Lu R, Brownley J, Lu B, Gerard C, Thomas K, et al. Gliadin induces an increase in intestinal permeability and zonulin release by binding to the chemokine receptor CXCR3. Gastroenterology. 2008;135(1):194-204 e3

12. Kamikubo Y, Dellas C, Loskutoff DJ, Quigley JP, Ruggeri ZM. Contribution of leptin receptor $\mathrm{N}$-linked glycans to leptin binding. Biochem J. 2008;410(3):595-604

13. Kuzma JN. Ingestion of wheat germ in healthy subjects does not acutely elevate plasma wheat germ agglutinin concentrations. Colorado State University: Libraries Digital Collections. 2009

14. Belderok B. Developments in bread-making processes. Plant Foods Hum Nutr. 2000;55(1):1-86

15. Day L, Augustin MA, Batey IL, Wrigley CW. Wheat-gluten uses and industry needs. Trends Food Sci Technol. 2006:17(2):82-90.

16. Soares FL, de Oliveira Matoso R, Teixeira LG, Menezes Z, Pereira SS, Alves AC, et al. Gluten-free diet reduces adiposity, inflammation and insulin resistance associated with the induction of PPAR-alpha and PPAR-gamma expression. J Nutr Biochem. 2013:24(6):1105-11.

17. Chirdo FG, Rumbo M, Anon MC, Fossati CA. Presence of high levels of non-degraded gliadin in breast milk from healthy mothers. Scand J Gastroenterol. 1998;33(11):1186-92.

18. Husby S, Jensenius JC, Svehag SE. Passage of undegraded dietary antigen into the blood of healthy adults. Quantification, estimation of size distribution, and relation of uptake to levels of specific antibodies. Scand Immunol. 1985:22(1):83-92.

19. Husby S, Jensenius JC, Svehag SE. Passage of undegraded dietary antigen into the blood of healthy adults. Further characterization of the kinetics of uptake and the size distribution of the antigen. Scand J Immunol. 1986:24(4):447-55

20. De Ritis G, Occorsio P, Auricchio S, Gramenzi F, Morisi G, Silano V. Toxicity of wheat flour proteins and protein-derived peptides for in vitro developing intestine from rat fetus. Pediatr Res. 1979;13(11):1255-61.

21. Mistrik P, Moreau F, Allen JM. BiaCore analysis of leptin-leptin receptor interaction: evidence for 1:1 stoichiometry. Anal Biochem. 2004;327(2):271-7.

22. Maffei M, Halaas J, Ravussin E, Pratley RE, Lee GH, Zhang Y, et al. Leptin levels in human and rodent: measurement of plasma leptin and ob RNA in obese and weight-reduced subjects. Nat Med. 1995;1(11):1155-61.

23. Considine RV, Sinha MK, Heiman ML, Kriauciunas A, Stephens TW, Nyce MR, et al. Serum immunoreactive-leptin concentrations in normal-weight and obese humans. N Engl J Med. 1996:334(5):292-5.

24. Caro JF, Kolaczynski JW, Nyce MR, Ohannesian JP, Opentanova I, Goldman $\mathrm{WH}$, et al. Decreased cerebrospinal-fluid/serum leptin ratio in obesity: a possible mechanism for leptin resistance. Lancet. 1996;348(9021):159-61.

\section{Submit your next manuscript to BioMed Central and take full advantage of:}

- Convenient online submission

- Thorough peer review

- No space constraints or color figure charges

- Immediate publication on acceptance

- Inclusion in PubMed, CAS, Scopus and Google Scholar

- Research which is freely available for redistribution 